\title{
Strength Behaviour of Cement Mortar with Marble Powder as Partial Replacement of Cement
}

\author{
Ganesan Nagalingam, Ramesh Babu Chokkalingam, Meyyappan PL
}

\begin{abstract}
In this study, the strength properties of marble powder in cement mortar have been investigated. The strength studies include compression test, split tensile test and flexure test. To perform these tests, a cement mortar is prepared in the ratio of $1: 3$ as per the Indian Standard guide lines. In this mortar, the cement is replaced by marble powder by 5\%, 10\%, 15\%, 20\%, 25\%, 30\%, 35\% and $40 \%$. For testing the compression strength behaviour of marble powder in replacement of cement, cement mortar cube specimens of size $7.07 \mathrm{~cm} \times 7.07 \mathrm{~cm} \times 7.07 \mathrm{~cm}$ are cast for all the said replacement ratios. After 7 and 28 days of curing, the specimens are tested for compression. Similarly for testing of splitting tensile strength, cylindrical mortar specimens of size $60 \mathrm{~mm}$ dia. and $120 \mathrm{~mm}$ are cast and tested at 7 and 28 days. For flexural strength determination, beam specimens of size $160 \mathrm{~mm} \times 40 \mathrm{~mm} \times 40 \mathrm{~mm}$ are cast and these specimens are tested after the required days of curing. From the test results, it has been found that the cement mortar mix with $10 \%$ marble powder gives better results in compression, split tension and in flexure results. To determine the oxide composition of marble powder, XRF test was performed.
\end{abstract}

Key words:, cement mortar, compressive strength, , flexural strength, marble powder, split tensile strength

\section{INTRODUCTION}

Marble is one of the construction material and used for flooring. In India, good quality marble deposits are wide spreading here and there. It is fine grained rock have uniform granular structure. Due to the increase in demand for construction materials like marble, a lot of companies both local and international companies dealing with marble are increasing in numbers every day. A good quality marble has all the properties of a good building stone. In the marble industries, to give a uniform shape to marble, the marble blocks are cut to small blocks. During the cutting and shaping process of marble, more than $25 \%$ of the marble blocks are converted into powder. This powder settles due to sedimentation, and then it is dumped somewhere within the industry which causes environmental pollution. In addition to this, it becomes a threat for agriculture and human health.

Revised Manuscript Received on December 5, 2019

* Correspondence Author

* Ganesan Nagalingam, Department of Civil Engineering, Kalasalingam Academy of Research and Education, Krishnankoil, Virudhunagar District, Tamilnadu .Email: civilganesan139@gmail.com

Ramesh Babu Chockkalingam, Department of Civil Engineering, Kalasalingam Academy of Research and Education Krishnankoil, Virudhunagar District, Tamilnadu .Email: babussr@gmail.com

Meyyappan PL, Department of Civil Engineering, Kalasalingam Academy of Research and Education ,Krishnankoil, Virudhunagar District, Tamilnadu .Email: meyyappan@klu.ac.in
Therefore it becomes absolutely necessary to dispose this marble waste properly or reuse it.

Many research works have been carried out to utilize this marble waste powder as a economical and eco-friendly material and have succeeded. When the marble dust is used as a replacement of fine aggregate in concrete, it has displayed an enhancing effect on compressive strength.[1] Some researchers found that, when marble dust is used as a replacement of cement, it has increased the compressive strength to a considerable amount[2,3] The partial replacement of cement and fine aggregate by marble powder or marble granules results in increase in workability and compressive strength of mortar and concrete.[4] When marble and lime stone dust is used an additive in concrete, the abrasion resistance and sodium sulphate resistance has been considerably increased[5] Hence an attempt is made here to study the strength properties of cement mortar using marble powder as a partial replacement of cement.

\section{MATERIALS USED}

\section{A. Cement:}

43 Grade Ordinary Portland Cement manufactured by M/s Chettinadu cement which confirms to Indian Standard specification of I.S. 8112-1989 is used in this experimental work. It is made use of casting the specimen, the cement used is taken from a single lot.[6]

\section{B. Marble powder:}

The fresh marble powder is collected from Annai Marbles, Madurai during the cutting process of marble stone. The chemical composition of marble powder is obtained by the XRF test and shown in the Table 1.

\section{Fine aggregate}

Locally available natural sand with $2.36 \mathrm{~mm}$ size is used in this work. This sand confirms to Zone 2 of IS 382-2016 having specific gravity value is 2.26 .[7]

\section{Water}

Potable water of good quality is used for mixing the concrete. It is free from alkalis and organic matters.

\section{E. Mortar mix preparation for the experimental work}

The cement and sand is mixed in the ratio of 1:3. Initially, these materials are weighed accurately to 0.01 gram and taken in a non-porous enamel tray and thoroughly mixed with the trowel for less than a minute. 


\section{Strength Behaviour of Cement Mortar with Marble Powder as Partial Replacement of Cement}

The water to be added to the mortar mix is determined by the formula (P/4 +3) \% of combined weight of cement and sand.

Table- I: Chemical composition of Marble powder by XRF analysis

\begin{tabular}{|c|l|c|}
\hline Sl.No & \multicolumn{1}{|c|}{ Characteristics } & Result \\
\hline 1. & Loss on ignition, \% by weight & 34.86 \\
\hline 2. & Silica $\left(\right.$ as $\left.\mathrm{SiO}_{2}\right), \%$ by weight & 16.99 \\
\hline 3. & Iron oxide $\left(\right.$ as $\left.\mathrm{Fe}_{2} \mathrm{O}_{3}\right), \%$ by weight & 0.52 \\
\hline 4. & Aluminium oxide $\left(\right.$ as $\left.\mathrm{Al}_{2} \mathrm{O}_{3}\right), \%$ by weight & 1.17 \\
\hline 5. & Titanium oxide $\left(\right.$ as $\left.\mathrm{TiO}_{2}\right), \%$ by weight & Nil \\
\hline 6. & Calcium oxide $($ as $\mathrm{CaO}), \%$ by weight & 39.89 \\
\hline 7. & Magnesium oxide $($ as $\mathrm{MgO}), \%$ by weight & 6.57 \\
\hline
\end{tabular}

F. Mix ID for various combinations of cement and marble powder

The various combinations of cement and marble powder used for preparing the specimens and total number of specimens prepared for testing are listed in the Table 2 below. A total of 198 specimens are cast for compressive strength, splitting tensile strength and flexural strength testing at 7 and 28 days curing.
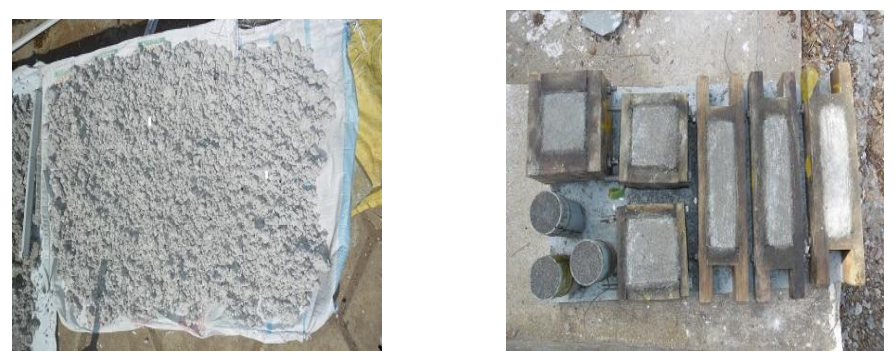

Fig.1. Marble powder preparation

Table- II: Materials for the experimental work

\begin{tabular}{|c|c|c|c|c|c|c|c|c|c|c|c|}
\hline Mix ID & M0 & M1 & M2 & M3 & M4 & M5 & M6 & M7 & M8 & M9 & M10 \\
\hline Cement (\%) & 100 & 95 & 90 & 85 & 80 & 75 & 70 & 65 & 60 & 55 & 50 \\
\hline Marble Powder (\%) & 0 & 5 & 10 & 15 & 20 & 25 & 30 & 35 & 40 & 45 & 50 \\
\hline No. of specimens & 18 & 18 & 18 & 18 & 18 & 18 & 18 & 18 & 18 & 18 & 18 \\
\hline
\end{tabular}

\section{EXPERIMENTAL WORK}

\section{A. Compression test:}

Using the controlled mix M0, cement mortar cubes of size $7.07 \mathrm{~cm} \times 7.07 \mathrm{~cm} \times 7.07 \mathrm{~cm}$ are cast. In the controlled mix, then the cement is replaced by marble powder from $5 \%$ to $50 \%$ with a variation of $5 \%$. Mortar cubes are also cast for these replacements for testing at 7 and 28 days. Three cubes are cast for each testing day in compression. After 24 hours of curing of specimens at room temperature, the cubes are removed from the moulds and subjected to water curing for the required days. After the required days of curing, the cubes are tested for compression in compression testing machine as

Table- III: Compressive strength test results shown in Fig 3. The average compressive strength results are tabulated in the Table 3 shown below and the comparison of compressive strength results are explained through Fig 4.

\begin{tabular}{|c|c|c|c|c|c|c|c|c|c|c|c|}
\hline Mix ID & M0 & M1 & M2 & M3 & M4 & M5 & M6 & M7 & M8 & M9 & M10 \\
\hline \\
Age of Curing (Days)
\end{tabular}

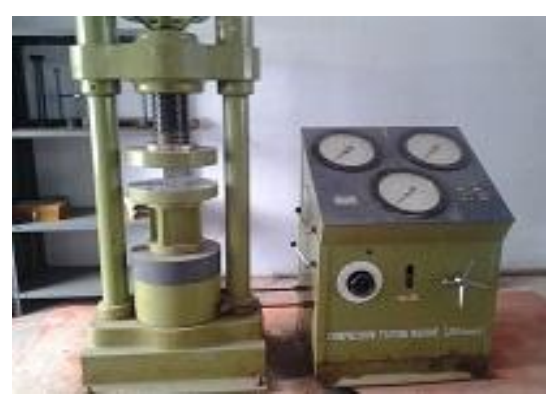

Fig.3.Compression test set up

B. Split tensile test 
To determine the split tensile strength of marble powder, mortar cylinders of $60 \mathrm{~mm}$ dia and $120 \mathrm{~mm}$ height are cast for the control mix. In the controlled mix, then the cement is replaced by marble powder from $5 \%$ to $50 \%$ with a variation of $5 \%$. Mortar cylinders are also cast for these replacements for testing at 7 and 28 days. Three cylinders are cast for each testing day in split tension. After 24 hours of curing of specimens at room temperature, the cylinders are removed from the moulds and subjected to water curing for the required days. After the required days of curing, the cylinders are tested for split tension in Universal testing machine as shown in Fig 5. The average split tensile strength results are tabulated in the Table 4 shown below and the comparison of split tensile values at 7 and 28 days are explained through Fig 6.

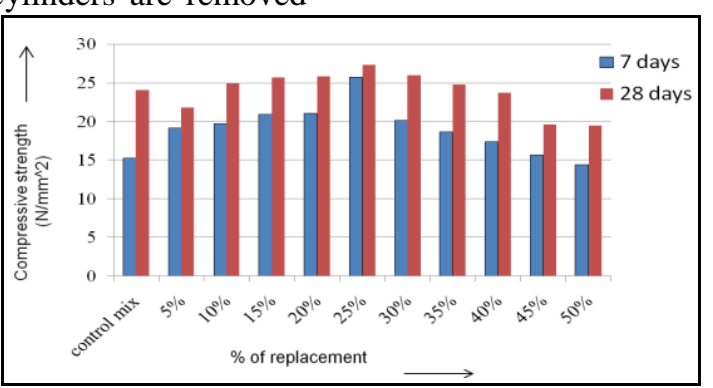

Fig.4. Comparison of compressive test results

Table- IV: Split tensile strength test results

\begin{tabular}{|c|c|c|c|c|c|c|c|c|c|c|c|}
\hline Mix ID & M0 & M1 & M2 & M3 & M4 & M5 & M6 & M7 & M8 & M9 & M10 \\
\hline Age of Curing (Days) & \multicolumn{11}{|c|}{ Average Split tensile Strength $\left(\mathrm{N} / \mathrm{mm}^{2}\right)$} \\
\hline 7 & 2.92 & 2.2 & 2.63 & 2.88 & 2.92 & 3.1 & 2.37 & 2.33 & 2.2 & 1.8 & 1.69 \\
\hline 28 & 2.99 & 2.63 & 2.71 & 2.88 & 3.13 & 3.22 & 2.71 & 2.54 & 2.37 & 2.16 & 1.95 \\
\hline
\end{tabular}

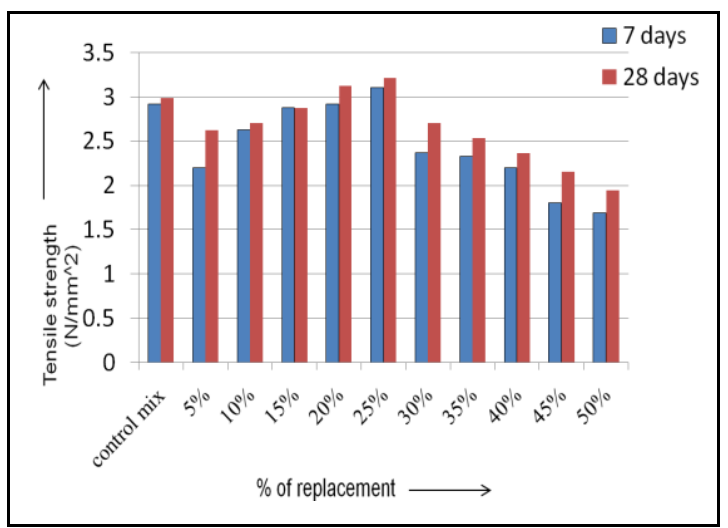

Fig.6. Comparison of split tensile test results

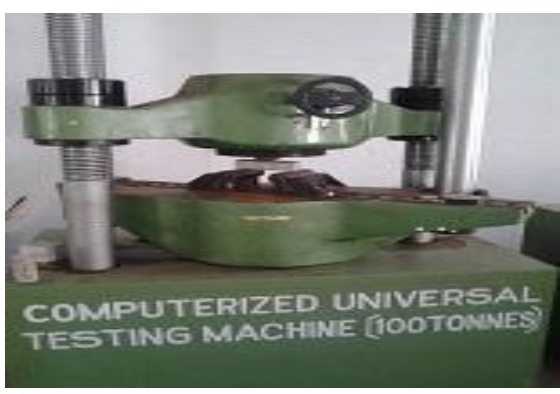

Fig.7.Flexure test set up 


\section{Strength Behaviour of Cement Mortar with Marble Powder as Partial Replacement of Cement}

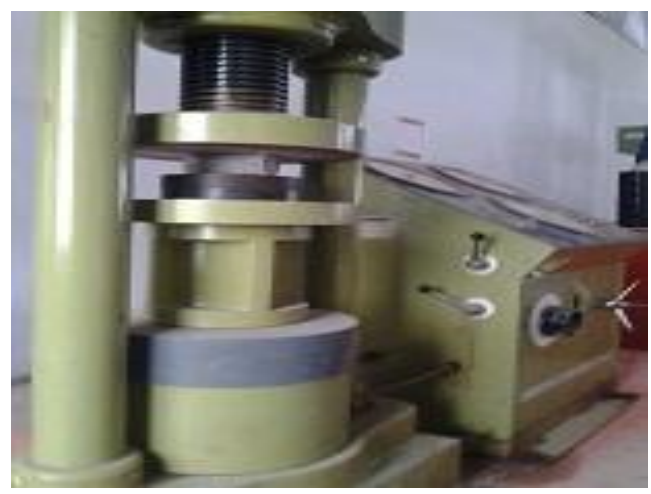

Fig.5.Split tensile test set up

\section{Flexure test}

To determine the flexural strength of marble powder, beam specimens of size $160 \mathrm{~mm}$ x $40 \mathrm{~mm}$ x $40 \mathrm{~mm}$ are cast for the control mix. Then in the controlled mix the cement is replaced by marble powder from $5 \%$ to $50 \%$ with a variation of $5 \%$. Mortar beam specimens are also cast for these replacements for testing at 7 and 28 days. Three beam specimens are cast for each testing day for determining the flexural strength values. After 24 hours of curing of

The comparative test results for all the tests are given in Table 6 specimens at room temperature, the beam specimens are removed from the moulds and subjected to water curing for the required days. After the required days of curing, the beam specimens are tested for flexure in Universal testing machine as shown in Fig 7. The average flexural strength results are tabulated in the Table 5 and the comparison of flexural strength values at 7 and 28 days are explained through Fig 8.

Table- V: Flexure strength test results

\begin{tabular}{|c|c|c|c|c|c|c|c|c|c|c|c|}
\hline Mix ID & M0 & M1 & M2 & M3 & M4 & M5 & M6 & M7 & M8 & M9 & M10 \\
\hline Age of Curing (Days) & \multicolumn{11}{|c|}{ Average Flexure Strength values(N/mm } \\
\hline 7 & $\begin{array}{c}10.2 \\
8\end{array}$ & $\begin{array}{c}10.7 \\
2\end{array}$ & $\begin{array}{c}11.0 \\
3\end{array}$ & $\begin{array}{c}11.7 \\
6\end{array}$ & $\begin{array}{c}12.0 \\
4\end{array}$ & $\begin{array}{c}12.5 \\
6\end{array}$ & $\begin{array}{c}11.8 \\
2\end{array}$ & $\begin{array}{c}10.7 \\
6\end{array}$ & 9.88 & 9.12 & 8.72 \\
\hline 28 & $\begin{array}{c}12.3 \\
4\end{array}$ & $\begin{array}{c}13.1 \\
2\end{array}$ & $\begin{array}{c}13.7 \\
8\end{array}$ & $\begin{array}{c}14.2 \\
2\end{array}$ & $\begin{array}{c}14.8 \\
9\end{array}$ & $\begin{array}{c}15.0 \\
2\end{array}$ & $\begin{array}{c}13.8 \\
8\end{array}$ & $\begin{array}{c}13.2 \\
4\end{array}$ & $\begin{array}{c}12.1 \\
2\end{array}$ & $\begin{array}{c}11.7 \\
8\end{array}$ & $\begin{array}{c}10.2 \\
4\end{array}$ \\
\hline
\end{tabular}

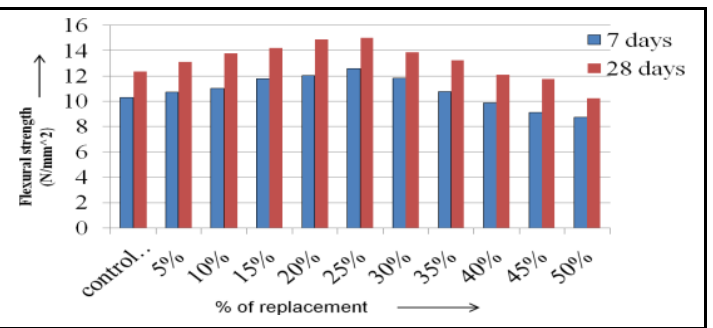

Fig.8.Comparision of flexure test results

\section{RESULTS WITH DUSCUSSION}

\section{A. Discussion on Compressive strength test results:}

From Table 3 of compressive strength values, it has been observed that at 7 days of specimen curing, the average compression strength value for control specimen (M0 Mix $-100 \%$ cement and $0 \%$ Marble powder) is $15.24 \mathrm{~N} / \mathrm{mm}^{2}$. When $5 \%$ cement is replaced by marble powder, this compression strength value increased to $19.18 \mathrm{~N} / \mathrm{mm}^{2}$. This value further increased for $10 \%, 15 \%, 20 \%$ and $25 \%$ of cement replacement by marble powder and reached the highest value of $25.71 \mathrm{~N} / \mathrm{mm}^{2}$ for $25 \%$ cement replacement (M5 mix). This is about $68.70 \%$ higher than the controlled mix specimens. Beyond this cement replacement for $30 \%$, $35 \%, 40 \%, 45 \%$ and $50 \%$, the strength is gradually reduced.
Similarly for 28 days of testing, the average compressive strength of Control specimen mix of M0 is $24.08 \mathrm{~N} / \mathrm{mm}^{2}$. This value increased for other replacement and reached the value

Table- VI: Comparative test results

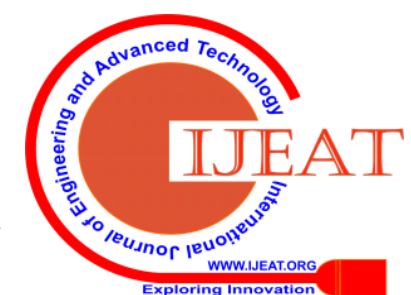




\begin{tabular}{|c|c|c|c|c|c|c|c|c|c|c|c|}
\hline Mix ID & M0 & Ml & M2 & M3 & M4 & M5 & M6 & M7 & M8 & M9 & Ml0 \\
\hline $\begin{array}{l}\text { Age of } \\
\text { Curing } \\
\text { (Days) }\end{array}$ & \multicolumn{11}{|c|}{ Average Compressive Strength $\left(\mathrm{N} / \mathrm{mm}^{2}\right)$} \\
\hline 7 & 15.24 & 19.18 & 19.72 & 20.55 & 21.08 & 25.71 & 20.13 & 18.63 & 17.41 & 15.64 & 14.42 \\
\hline 28 & 24.08 & 21.76 & 24.89 & 25.71 & 25.84 & 27.34 & 25.98 & 24.76 & 23.67 & 19.59 & 19.45 \\
\hline $\begin{array}{l}\text { Age of } \\
\text { Curing } \\
\text { (Days) }\end{array}$ & \multicolumn{11}{|c|}{ Average Split tensile Strength $\left(\mathrm{N} / \mathrm{mm}^{2}\right)$} \\
\hline 7 & 2.92 & 2.20 & 2.63 & 2.88 & 2.92 & 3.1 & 2.37 & 2.33 & 2.20 & 1.80 & 1.69 \\
\hline 28 & 2.99 & 2.63 & 2.71 & 2.88 & 3.13 & 3.22 & 2.71 & 2.54 & 2.37 & 2.16 & 1.95 \\
\hline $\begin{array}{l}\text { Age of } \\
\text { Curing } \\
\text { (Days) }\end{array}$ & \multicolumn{11}{|c|}{ Average Flexure Strength values $\left(\mathrm{N} / \mathrm{mm}^{2}\right)$} \\
\hline 7 & 10.28 & 10.72 & 11.03 & 11.76 & 12.04 & 12.56 & 11.82 & 10.76 & 9.88 & 9.12 & 8.72 \\
\hline 28 & 12.34 & 13.12 & 13.78 & 14.22 & 14.89 & 15.02 & 13.88 & 13.24 & 12.12 & 11.78 & 10.24 \\
\hline
\end{tabular}

\section{B. Discussion on Splitting tensile strength test results:} of $27.34 \mathrm{~N} / \mathrm{mm}^{2}$ for $25 \%$ cement replacement. This is about $13.50 \%$ higher than the control mix specimens. The compressive strength values are decreasing for increased replacement value of cement by marble powder from $30 \%$ to $50 \%$. From these compressive strength results, it is clear that $25 \%$ of cement can be replaced by $25 \%$ of marble powder for having better strength values.

From the compressive test results it is observed that there is a strength increment of $68 \%$ for M5 specimens from M0 specimens at 7 days whereas at 28 days, this increment is about $13.5 \%$ only and further it starts decreasing.

From Table 4 of splitting tensile strength results, it has been noted that at 7 days of testing, the average split tensile strength value for control specimen (M0 Mix $-100 \%$ cement and $0 \%$ Marble powder) is $2.92 \mathrm{~N} / \mathrm{mm}^{2}$. When $5 \%$ cement is replaced by marble powder, this split tensile strength value is reduced to $2.20 \mathrm{~N} / \mathrm{mm}^{2}$. This value is further increased gradually for $10 \%, 15 \%, 20 \%$ and $25 \%$ of cement replacement by marble powder and reached the value of 3.1 $\mathrm{N} / \mathrm{mm}^{2}$ for $25 \%$ replacement. This value is $6 \%$ higher than the control mix specimen values. Higher cement replacement of $30 \%$ to $50 \%$ with a variation of $5 \%$, the results gradually decreased and reached the value of $1.69 \mathrm{~N} / \mathrm{mm}^{2}$ for $25 \%$ cement replacement by marble powder.

For 28 days, the average split tensile strength value for Control specimen mix is $2.99 \mathrm{~N} / \mathrm{mm}^{2}$. This value reached to $3.22 \mathrm{~N} / \mathrm{mm}^{2}$ for $25 \%$ cement replacement. This is about 7.69 $\%$ higher than the control mix specimens. For other replacements of $30 \%$ to $50 \%$, the value started decreasing further. Like compressive strength results, it is evident that $25 \%$ cement can be replaced by marble powder which performs well for split tension.

From the splitting tensile strength test results it is observed that there is a strength increment of $6 \%$ for M5 specimens from M0 specimens at 7 days whereas at 28 days, this increment is about $8 \%$ only and further it starts decreasing.

\section{Discussion on Flexural strength test results:}

From Table 5 of flexural strength test results, it has been observed that at 7 days of testing, the average flexural strength value for control specimen (M0 Mix $-100 \%$ cement and $0 \%$ Marble powder) is $10.28 \mathrm{~N} / \mathrm{mm}^{2}$. When $5 \%$ cement is replaced by marble powder, this flexural strength value increased to $10.72 \mathrm{~N} / \mathrm{mm}^{2}$. This value further increased for

$10 \%, 15 \%, 20 \%$ and $25 \%$ of cement replacement by marble powder and reached the highest value of $12.56 \mathrm{~N} / \mathrm{mm}^{2}$ for $25 \%$ cement replacement (M5 mix). This is about $22.12 \%$ higher than the controlled mix specimens. Beyond this cement replacement for $30 \%, 35 \%, 40 \%, 45 \%$ and $50 \%$, the flexural strength is gradually reduced.

Similarly for 28 days of testing, the average flexural strength of Control specimen mix of M0 is $12.34 \mathrm{~N} / \mathrm{mm}^{2}$. This value increased further for other replacements and reached the value of $15.02 \mathrm{~N} / \mathrm{mm}^{2}$ for $25 \%$ cement replacement. This is about $21.72 \%$ higher than the control mix specimens. The flexural strength values are further decreased for increased replacement value of cement by marble powder from $30 \%$ to $50 \%$. From these results, it has been observed that $25 \%$ of cement can be replaced by $25 \%$ of marble powder for having good flexure values.

From the flexure test results it is observed that there is a strength increment of $22.17 \%$ for M5 specimens from M0 specimens at 7 days whereas at 28 days, this increment is about $21.71 \%$ and further it starts decreasing.

\section{V.CONCLUSIONS}

The conclusions based on the observations from the present investigation on strength properties of cement mortar with partial replacement of cement by marble powder are as follows.

(i) The compression, flexural and split tensile strengths initially increases and then start decreases with increase in marble powder. Cement mortar of $1: 3$ mixes with $75 \%$ cement and $25 \%$ Marble powder gives good values in all the three strength tests.

(ii) Since, marble powder is one of the industrial waste material and obtained at free of cost, the replacement of cement by marble powder proves to be more economical than conventional cement mortar mix.

(iii) A solution of disposing the industrial waste is found out and the problem of threat to agriculture and health is minimized to a greater extent.

Published By: 


\section{Strength Behaviour of Cement Mortar with Marble Powder as Partial Replacement of Cement}

(iv) Since the workability of concrete is good at initial stages upto $25 \%$ replacement of cement by marble powder, the strength is initially in an increasing trend whereas the workability starts decreasing beyond $25 \%$ and due to the non- uniform mixing of materials and others the strength starts decreasing.

\section{REFERENCES}

[1] Bahar Demirel, "The effect of the using marble dust as fine sand on the mechanical properties of the concrete" International Journal of the Physical Sciences, 2010, pp 1372-1380.

[2] Animesh Mishra, Abhishek Pandey, Prateek Maheshwari, Abhishek Chouhan, S. Suresh, Shaktinath Das, Green Cement For Sustainable Concrete Using Marble Dust", International Journal of ChemTech Research , 2013, pp 616-622, 2013

[3] Shirule A.P, Ataur Rahman, Rakesh D Gupta, "Partial Replacement of Cement with Marble Powder", International Journal of Advanced Engineering Research and Studies, 2012, 175-177.

[4] Baboo Rai, Khan Naushad H, Abhishek Kr, Tabin Rushad S, Duggal S $\mathrm{K}$, "Influence of Marble Powder/granules in Concrete mix" International Journal of Civil and Structural Engineering, 2014,pp 827-834

[5] Hanifi Binici, Hasan Kaplan, Salih Yilmaz, “Influence of Marble and Lime stone dusts as additives on some mechanical properties of concrete", Scientific Research and Essay , 2007, pp 372-379, 2007

[6] IS 8112-1989 Specification for 43 Grade Ordinary Portland cement, Bureau of Indian Standards, New Delhi

[7] Indian Standard Code of practice for specification for coarse and fine aggregates from natural sources for concrete, IS: 383 - 1970, Bureau of Indian Standards, New Delhi, India

[8] PL. Meyyappan, K.Kumaran, M.Gopalakrishnan and E. Harikrishnan (2018), "Effect of glass fibers, flyash and quarry ash on Strength and Durability Aspects of Concrete - An Experimental Study", IOP Conference Series: Material Science and Engineering, doi:10.1088/1757-899X/396/1/012001.

[9] PL. Meyyappan, K.Kumaran, M.Gopalakrishnan and E. Harikrishnan (2018), "Experimental Investigation on the Effect of Silica fume and Pumice stone in Developing Light Weight Concrete", IOP Conference Series: Material Science and Engineering, doi:10.1088/1757-899X/561/1/012064.

[10] PL. Meyyappan, P. Amuthakannan, R. Sutharsan and M. Ahamed Azik Ali (2019), "Utilization of M-Sand \& Basalt Fiber in Concrete: An Experimental Study on Strength and Durability Properties", IOP Conference Series: Material Science and Engineering, doi:10.1088/1757-899X/561/1/012035.

\section{AUTHORS PROFILE}

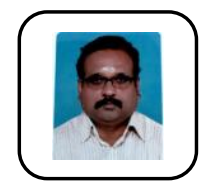

Ganesan Nagalingam completed his UG in Civil Engg. from A.C.Tech, Karaikudi and PG in Structural Engineering from Annamalai University, and pursuing his $\mathrm{PhD}$ from Kalasalingam Academy of Research and Education. He has more than twenty five years of experience in teaching and industry. His areas of research include geopolymer concrete, high performance concrete etc.

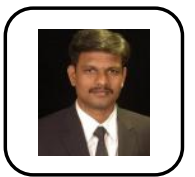

Ramesh Babu Chokkalingam completed his $\mathrm{Ph} . \mathrm{D}$. from IIT Chennai. He has more than ten years of experience in teaching and research. His areas of research includes pervious concrete, geopolymer concrete, and high volume flyash concrete.

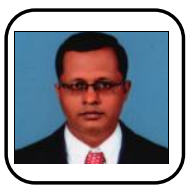

Dr. PL. Meyyappan has completed his graduation and post-graduation from Bharathiyar University and Karunya University respectively. He completed his $\mathrm{PhD}$ from Kalasalingam University. He has 13 years of teaching experience. He has completed 2 sponsored research projects from TNSCST and published more than 25 papers in peer reviewed journals and conferences. He is a life member in ISTE, IEI, IGS, ISET, ISRS. He is serving as Editorial Board Member and Reviewer in various reputed Journals. 